\title{
Optimal energy management system for distribution systems using simultaneous integration of PV-based DG and DSTATCOM units
}

\section{Adel Lasmari ${ }^{1}$,}

Mohamed Zellagui ${ }^{2,3}$,

Rachid Chenni ${ }^{1}$,

Smail Semaoui ${ }^{4}$,

Claude Ziad El-Bayeh ${ }^{5}$,

Heba Ahmed Hassan ${ }^{6}$

${ }^{1}$ MoDERNa Laboratory,

Department of Electrotechnic,

Mentouri University of Constantine 1,

Constantine, Algeria

Email:adel.lasmari@umc.edu.dz,

rachid.chenni@umc.edu.dz

${ }^{2}$ Department of Electrical Engineering, École de Technologie Supérieure (ÉTS),

Montréal, Québec, Canada

${ }^{3}$ Department of Electrical Engineering, Faculty of Technology,

University of Batna 2, Fesdis, Batna, Algeria

Email:m.zellagui@ieee.org,

m.zellagui@univ-batan2.dz

${ }^{4}$ Division Énergie Solaire Photovoltaïque,

Centre de Développement

des Energies Renouvelables (CDER),

Algiers, Algeria

Email:s.semaoui@cder.dz

${ }^{5}$ Canada Excellence Research Chairs Team,

Concordia University, Montréal, Québec, Canada

Email:c.bayeh@hotmail.com

${ }^{6}$ Department of Electrical Power Engineering,

Cairo University, Giza, Egypt

Email:hebahassan@ieee.org
The energy management system (EMS) of an electrical distribution system (EDS), with the integration of distributed generation (DG) and distribution static compensator (DSTAT$\mathrm{COM}$ ), provides numerous benefits and significantly differs from the existing EDSs. This paper presents an optimal integration of DG based on photovoltaic (PV) solar panels and DSTATCOM in EDS. A single objective function, based on maximizing the active power loss level (APLL) in EDS, is deployed to find the optimal size and location of photovoltaic DG and DSTATCOM simultaneously in different study cases using various particle swarm optimization (PSO) algorithms. These PSO algorithms are the basic PSO, adaptive acceleration coefficients PSO (AAC-PSO), autonomous particles groups for PSO (APG-PSO), nonlinear dynamic acceleration coefficients PSO (NDAC-PSO), sine cosine acceleration coefficients PSO (SCAC-PSO), and time-varying acceleration PSO (TVA-PSO). These algorithms are applied to the standard IEEE 33- and 69-bus EDSs, which are used as test systems to verify the effectiveness of the proposed algorithms. Simulation results prove that the TVA-PSO algorithm exhibits higher capability and efficiency in finding optimum solutions. Comparing the simulation results attained for different study cases leads to the conclusion that DG and DSTATCOM were optimally-allocated simultaneously, which resulted in a significant reduction of power losses and an enhancement of the voltage profile.

Keywords: energy management system (EMS), electrical distribution system (EDS), renewable energy resources (RES), distributed generation (DG), distribution static compensator (DSTATCOM), active power loss level, particle swarm optimization algorithm 


\section{INTRODUCTION}

The demand for electricity has recently increased due to the ongoing urbanization and the industrial revolution. In early ages, electric demand was mainly fulfilled by fossil fuel-based power generation, which nowadays constitutes a serious threat to environment. In order to address this problem, the renewable energy-based power generation in the electrical distribution system (EDS) has become of great interest and importance. The integration and utilization of renewable energy sources in the existing conventional EDSs are becoming more attractive and valuable due to their technical and economic impacts [1]. In the present-day scenario, power system utilities are operating closer to the stability margin because of an enormous load growth and an undesired power flow, depending on the energy efficiency policy in the country $[2,3]$. The energy management system (EMS) is the central control unit for an EDS, which would control the power flow among the elements of the system and with regard to the external grid.

The expansion of an existing EDS or the construction of new centralized generation units has become not practically feasible because of various restrictions [4]. These issues divert the attention of EDS planners towards the simultaneous deployment of distributed generation (DG) and distribution static compensator (DSTATCOM) $[5,6]$. In order to enhance the stability and power quality of the system, DSTATCOM is used in the EDS to automatically compensate reactive power according to the system variable loads [7].

In literature, issues and challenges of EDS can be addressed through several solutions. $\mathrm{Nu}-$ merous algorithms have been developed by researchers to address the best allocation of simultaneous deployment of DG and DSTATCOM in EDS. Some of the algorithms used in 2018 were, for example, the applied cuckoo searching algorithm (CSA) [8], improved PSO algorithm based on success rate (IPSO-SR) [9], flower pollination algorithm (FPA) [10], honey bees mating optimization (HBMO) algorithm [11] and water cycle algorithm (WCA) [12]. In 2019, examples of the algorithms used were the applied rooted tree optimization (RTO) [13], improved crow search algorithm (ICSA) [14], multi-verse optimizer (MVO) algorithm [15], modified bat algorithm (MBA) [16] and artificial fish swarm optimization algorithm (AFSOA) [17]. Recently in 2020, the applied discrete rooted tree optimization (DRTO) technique [18], Latin hypercube sampling (LHS) algorithm [19] and whale optimization algorithm (WOA) [20] were used.

This paper presents a new approach for the identification of the optimal location and size of photovoltaic source-based DG and DSTATCOM simultaneously into EDS using various PSO algorithms. The algorithms are based on the variation of acceleration coefficients (cognitive and social values), which aim to maximize the active power loss level (APLL) and improve the voltage profile of EDS. The algorithms are tested on two different standard IEEE 33- and 69bus EDS systems using the following algorithms: basic PSO, AAC-PSO, APG-PSO, NDAC-PSO, SCAC-PSO and TVA-PSO. From comparing the optimization results of the TVA-PSO algorithm with the rest of PSO applied algorithms to the test systems, it can be deduced that the results obtained using the TVA-PSO algorithm are better in terms of maximizing the APLL.

\section{PROBLEM FORMULATION AND CONSTRAINTS}

\section{The objective function}

The main objective function to be maximized is the APLL, i.e. maximizing the reduction of active power loss:

$$
\text { Objective Function }=\operatorname{Max} \sum_{i=1}^{N_{B u s}} \sum_{j=2}^{N_{B u s}} A P L L(i, j) .
$$

Here,

$$
\begin{aligned}
& \operatorname{APLL}(i, j)= \\
& \frac{P_{\text {Loss }}^{\text {Before DG/DSTATCOM }}}{P_{\text {Loss }}^{\text {Before DG/DSTATCOM }}+P_{\text {Loss }}^{\text {After DG/DSTATCOM }}} \times 100 \% .
\end{aligned}
$$

The active power loss on the distribution line connecting bus $i$ to bus $j[21,23]$ is represented by the following equation:

$$
P_{\text {Loss }}(i, j)=\alpha_{i j}\left(P_{i} P_{j}+Q_{i} Q_{j}\right)+\beta_{i j}\left(Q_{i} P_{j}+P_{i} Q_{j}\right) \text {. }
$$


Here,

$$
\begin{aligned}
& \alpha_{i j}=\frac{R_{i j}}{V_{i} V_{j}} \cos \left(\delta_{i}-\delta_{j}\right), \\
& \beta_{i j}=\frac{R_{i j}}{V_{i} V_{j}} \cos \left(\delta_{i}-\delta_{j}\right) .
\end{aligned}
$$

\section{Distribution line constraints}

Power conservation constraint [21-24]:

$$
\begin{aligned}
& P_{G}+P_{D G}=P_{D}+P_{\text {Loss }} \\
& Q_{G}+Q_{\text {DSTATCOM }}=Q_{D}+Q_{\text {Loss }} .
\end{aligned}
$$

Bus voltage limits:

$$
V_{\min } \leq\left|V_{i}\right| \leq V_{\max }
$$

Voltage drop limit:

$$
\left|1-V_{i}\right| \leq \Delta V_{\max }
$$

Line capacity limit:

$$
\left|S_{i j}\right| \leq\left|S_{\max }\right| .
$$

\section{DG constraints}

Inequality constraints represent the DG unit's limits [21, 23], which can be given by

$$
\begin{aligned}
& P_{D G}^{\min } \leq P_{D G} \leq P_{D G}^{\max }, \\
& \sum_{i=1}^{N_{D G}} P_{D G}(i) \leq \sum_{j=1}^{N_{b u s}} P_{D G}(i), \\
& 2 \leq D G_{\text {Position }} \leq N_{\text {Bus }}, \\
& N_{\text {DG }} \leq N_{\text {DG.max }}
\end{aligned}
$$

$$
n_{D G, i} / \text { Location } \leq 1
$$

\section{DSTATCOM constraints}

Inequality constraints represent the DSTATCOM unit's limits which can formulate as follows [15]:

$$
Q_{\mathrm{DSTATCOM}}^{\min } \leq Q_{\text {DSTATCOM }} \leq Q_{\mathrm{DSTATCOM}}^{\max }
$$

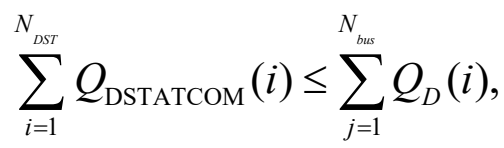

$$
2 \leq \text { DSTATCOM }_{\text {Position }} \leq N_{\text {Bus }}
$$

$N_{\text {DSTATCOM }} \leq N_{\text {DSTATCOM.max }}$

$$
n_{\text {DSTATCOM,i }} / \text { Location } \leq 1 .
$$

\section{OVERVIEW OF VARIOUS PSO}

\section{ALGORITHMS}

The PSO algorithm was first introduced in 1995, which can be seen as a global search technique. In this algorithm, each particle, denoted by $i$, has a velocity vector $\left(V_{i}\right)$ and a position vector $\left(X_{i}\right)$. It can be represented by the following equations [25]:

$$
\begin{aligned}
& V_{i}^{k+1}=\omega \cdot V_{i}^{k}+c_{1} r_{1}\left[P_{\text {best }}^{k}-X_{i}^{k}\right]+ \\
& \mathrm{c}_{2} r_{2}\left[G_{\text {best }}^{k}-X_{i}^{k}\right], \\
& X_{i}^{k+1}=X_{i}^{k}+V_{i}^{k+1} .
\end{aligned}
$$

Various novel PSO algorithms, in which timevarying acceleration coefficients are included, are applied in this paper. These PSO algorithms are shown in Table 1.

Different time-varying updating strategies for $c_{1}$ and $c_{2}$ acceleration coefficients for various PSO algorithms are represented in Fig. 1.

Table 1. Various equations of PSO algorithms applied

\begin{tabular}{c|c|c|c}
\hline Algorithm & Ref. & Acceleration coefficients formula & Constants \\
\hline AAC-PSO & [26] & $c_{1}=c_{\text {min }}+\left(c_{\max }-c_{\text {min }}\right) e^{-\left(\frac{4 \times k}{k_{\max }}\right)^{2}}$ & $c_{\text {min }}=0.5$ \\
& & $c_{2}=c_{\max }-\left(c_{\max }-c_{\min }\right) e^{-\left(\frac{4 \times k}{k_{\max }}\right)^{2}}$ & $c_{\max }=2.5$ \\
\hline
\end{tabular}


Table 1. (Continued)

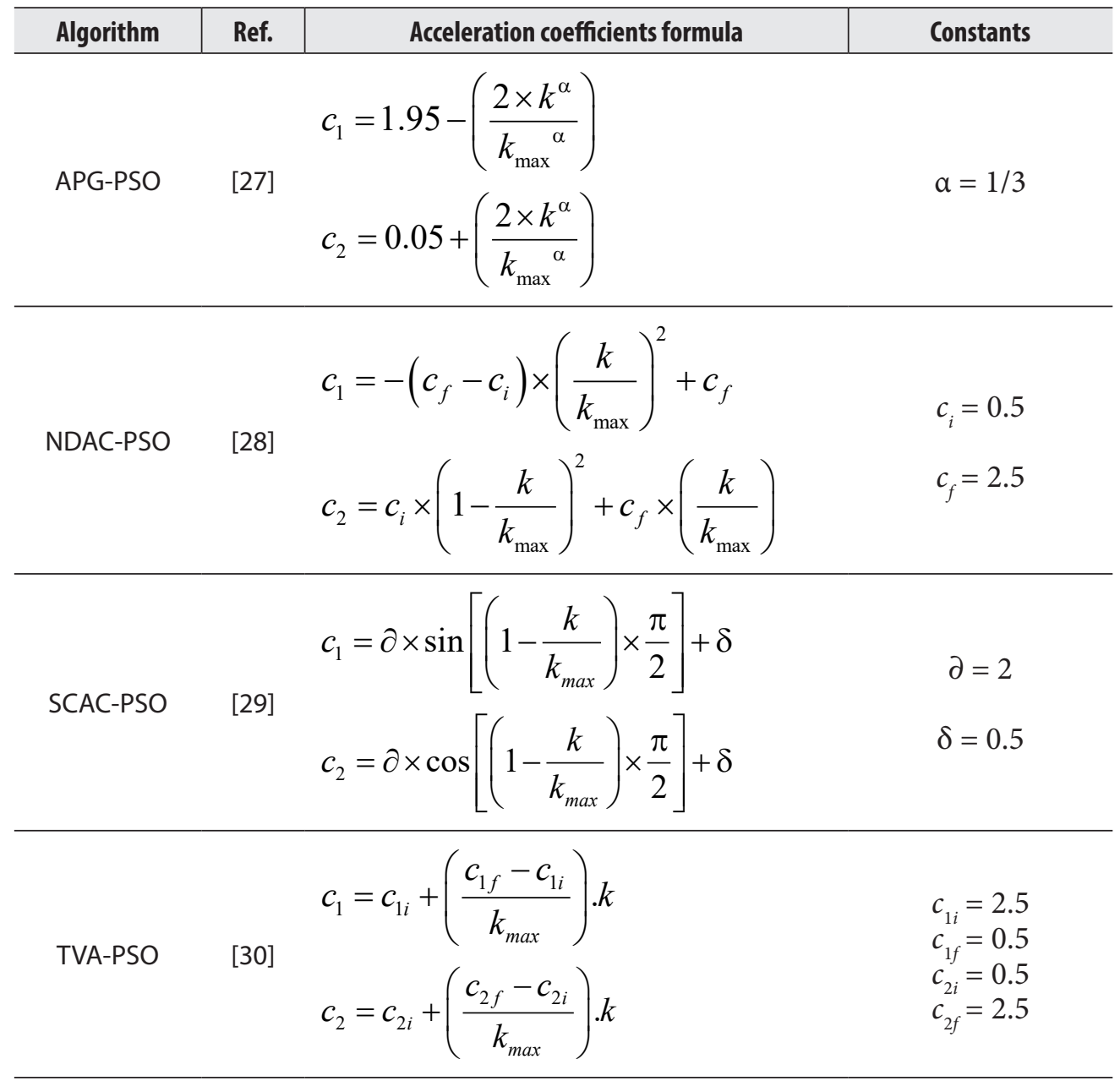
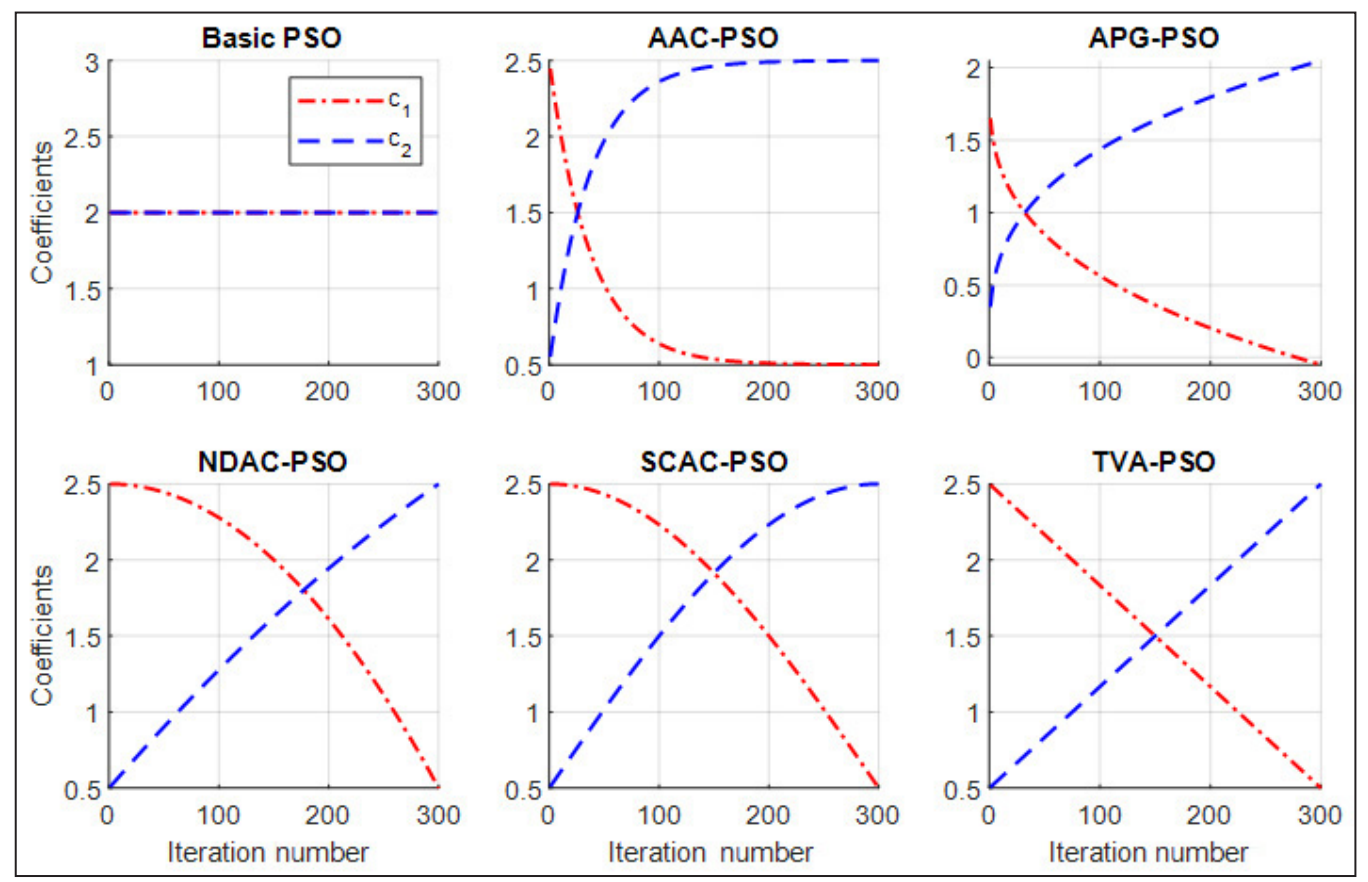

Fig. 1. Variation of acceleration coefficients for PSO algorithms applied 
As shown in Fig. 1, while using the basic PSO algorithm, despite the variation of the number of iterations, the acceleration coefficients $c_{1}$ and $c_{2}$ are constant. However, in other algorithms, the acceleration coefficients vary with iterations.

Furthermore, $c_{1}$ is decreased from 2.5 to 0.5 for all the algorithms except for APG-PSO, in which $c_{1}$ varies from 1.65 to 0 . On the other hand, $c_{2}$ is increased from 0.5 to 2.5 for almost all algorithms except for APG-PSO, in which $c_{2}$ varies from 0.35 to 2.05 . It is also noticed that the AAC-PSO shows a rapid variation to retain a stable form, whereas the NDAC-PSO takes longer for $c_{2}$ to be greater than $c_{1}$.

\section{TEST SYSTEMS, RESULTS AND COMPARISON}

Various PSO algorithms are implemented in MATLAB and applied to two standard IEEE distribution systems. The first test system used in this study is the standard IEEE 33-bus EDS represented in Fig. 2(a), which is composed of 33 buses and 32 distribution lines. The active and reactive power losses calculated from power flow are $210.987 \mathrm{~kW}$ and $143.128 \mathrm{kVar}$, respectively. Fig. 2(b) represents the second test system, which is the standard IEEE 69-bus EDS, that is composed of 69 buses and 68 distribution lines. The active and reactive power losses in the EDS are $224.948 \mathrm{~kW}$ and $102.140 \mathrm{kVar}$, respectively. The base voltage of the two EDSs is $12.66 \mathrm{kV}$.

\section{Comparison among various algorithms applied}

The convergence optimization characteristics of various PSO algorithms proposed for the two distribution systems, in the presence of both DG and DSTATCOM, are presented in Fig. 3.

Results of the IEEE 33-bus system are shown in Fig. 3(a) for various algorithms, where all algorithms converge in 10 to 150 iterations. Among these algorithms, the TVA-PSO, APG$\mathrm{PSO}$ and AAC-PSO are faster in convergence as the optimal solution is reached in less than 50 iterations. The optimal values of APLL are close to each other for almost all of the algorithms, and they are around $90 \%$ of the initial values.

For the IEEE 69-bus, Fig. 3(b) clearly shows that all the algorithms take a long time to reach the optimal solution, with more than 170 iterations, except for the basic PSO that converges in 130 iterations. On the other hand, the TVAPSO encountered the best APLL, but it takes 260 iterations to achieve the optimal solution. The maximum values of APLL are not much far from each other; moreover, it can be noted that the best results are obtained by TVAPSO for the two test systems. These values are 90.2161 and $95.4715 \%$, respectively. In addition, it is noted that the first test system converges faster when compared with the second system.

Figure 4 illustrates the boxplot of APLL using various PSO algorithms applied to the two test systems.

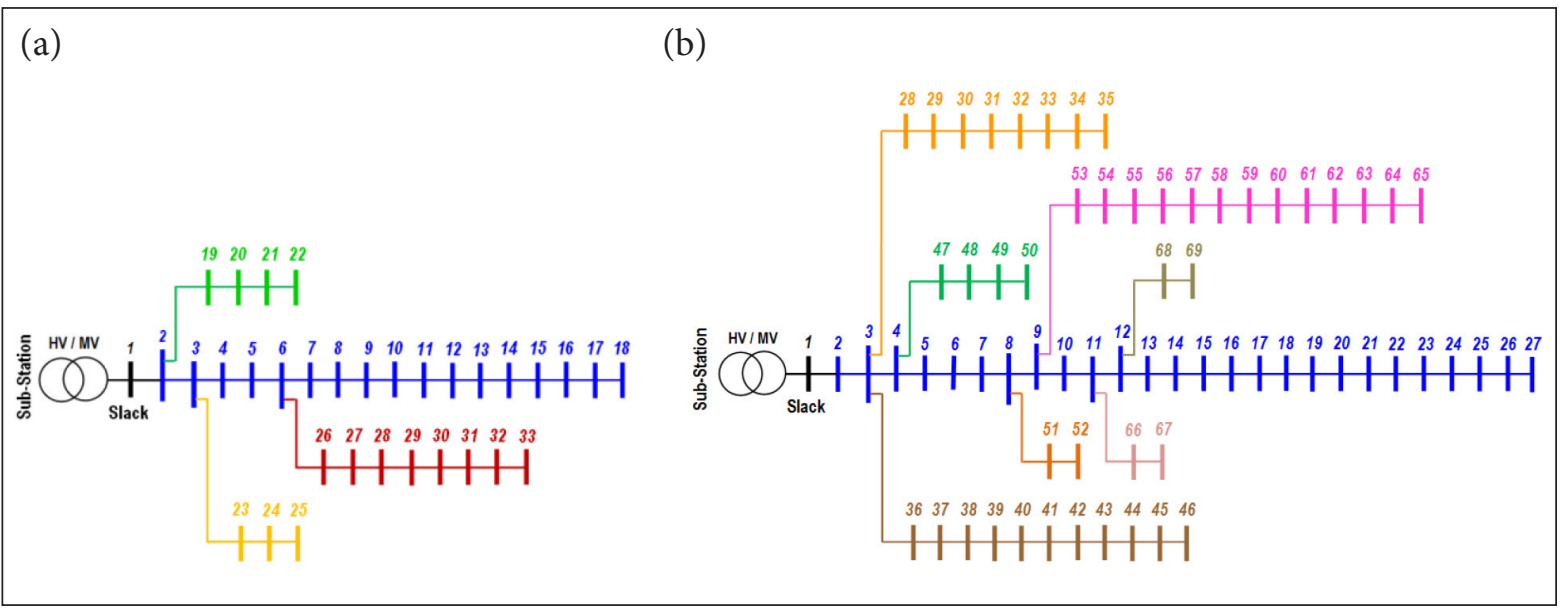

Fig. 2. Single line diagram of standard EDS: (a) IEEE 33-bus, (b) IEEE 69-bus 


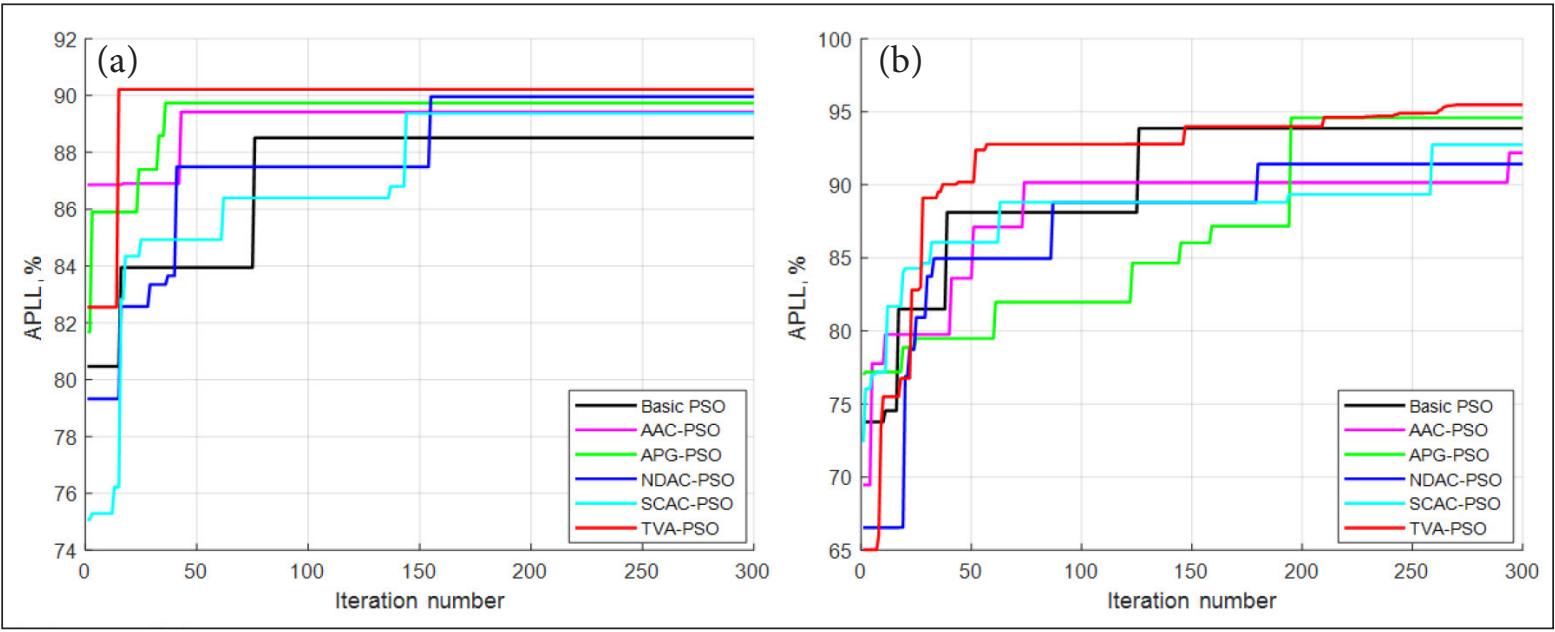

Fig. 3. Convergence curves of various PSO algorithms: (a) IEEE 33-bus, (b) IEEE 69-bus

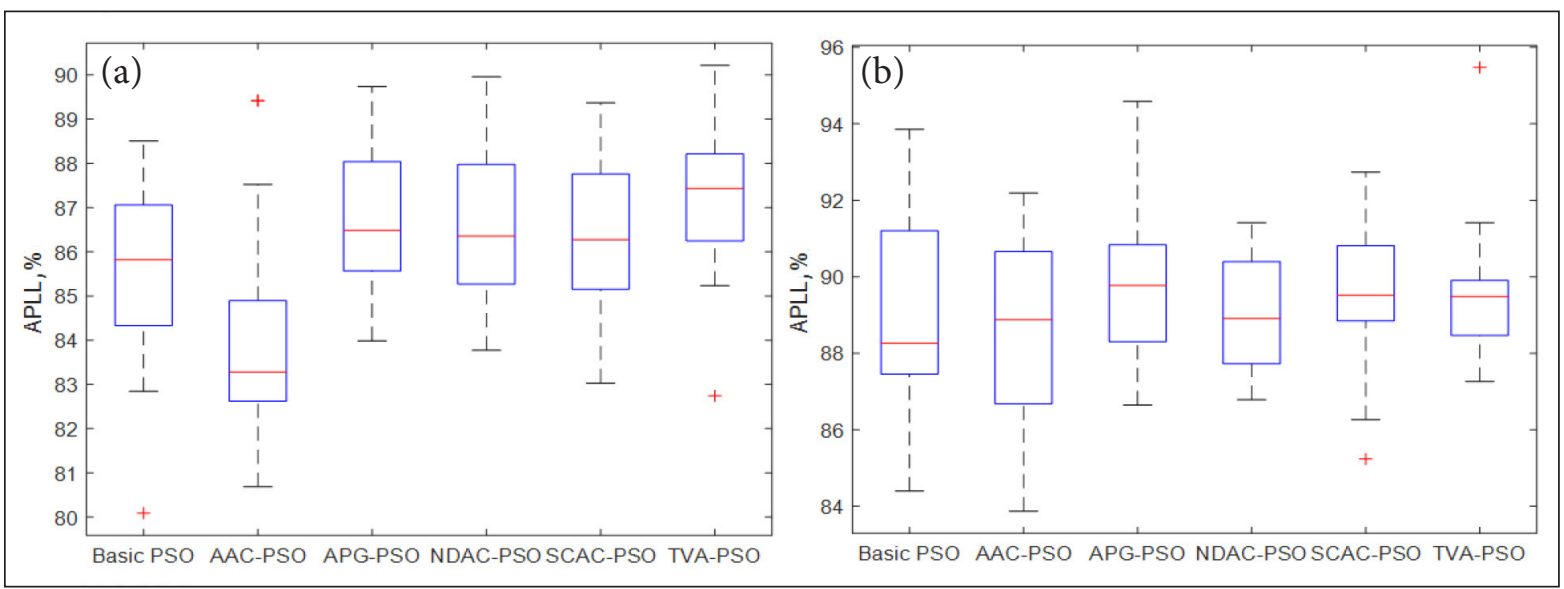

Fig. 4. Boxplot of APLL for various PSO algorithms: (a) IEEE 33-bus, (b) IEEE 69-bus

Considering the results of both test systems as in Fig. 4, while taking into account the same number of iterations and population size, the boxplots prove that the results of all algorithms applied are close to each other. Furthermore, the best (maximum) APLL results are obtained when using the TVA-PSO algorithm.

The results of the test systems after the installation and optimization of the simultaneously used DG and DSTATCOM are presented in Table 2.

The analysis of the results tabulated in Table 2 for the first test system (IEEE 33-bus system) reveals that the integration of DG and DSTATCOM units simultaneously contributes to minimizing the total power loss to acceptable values for all the algorithms. The best result of APLL is obtained by applying the TVA-PSO algorithm that chooses buses 13,24 and 30 as an optimal location for the integration of DG units, with a total size of 2.3251 MW. Simultaneously, buses 4, 29 and 30 are found to be the best location for the integration of DSTATCOM units, with a total size of 1.9985 MVar. This integration led to reducing the active power loss from 210.9875 to $22.8821 \mathrm{~kW}$ with a reduction percentage of up to $89.1547 \%$. In addition, the APLL was maximized to $90.2161 \%$. On the other hand, the minimum reactive power loss is obtained when using the NDAC-PSO algorithm, which is $17.2421 \mathrm{kVar}$. The minimum voltage is increased from 0.9038 to 0.9907 p.u. when using the AACPSO algorithm.

For the second test system (IEEE 69-bus system), the TVA-PSO algorithm identifies the buses 
Table 2. Optimization results of simultaneous installation of DG and DSTATCOM

(a) IEEE 33-bus

\begin{tabular}{|c|c|c|c|c|c|c|}
\hline & $\begin{array}{c}\text { DG } \\
P(\mathrm{MW}) ; \text { Bus }\end{array}$ & $\begin{array}{l}\text { DSTATCOM } \\
\text { Q (MVar); Bus }\end{array}$ & $P_{\text {Loss }}, \mathbf{k W}$ & $Q_{\text {Loss' }}, \mathbf{k V a r}$ & $V_{\min ^{\prime}}$ p.u. & $A P L L, \%$ \\
\hline \multirow{3}{*}{ Basic PSO } & $1.0154(9)$ & $0.6034(8)$ & & & & \\
\hline & $0.3514(24)$ & $0.4663(22)$ & 27.3993 & 20.3035 & 0.9750 & 88.5063 \\
\hline & $0.8445(30)$ & $0.8567(30)$ & & & & \\
\hline \multirow{3}{*}{ AAC-PSO } & $0.8507(14)$ & $0.0100(3)$ & & & & \\
\hline & $0.8103(25)$ & $0.6906(26)$ & 24.9642 & 20.7094 & 0.9907 & 89.4202 \\
\hline & $1.3916(29)$ & $0.7237(32)$ & & & & \\
\hline \multirow{3}{*}{ APG-PSO } & $0.5494(15)$ & $0.7407(8)$ & & & & \\
\hline & $1.0485(24)$ & $0.3521(29)$ & 24.1281 & 18.0946 & 0.9785 & 89.7378 \\
\hline & $0.7655(30)$ & $0.4405(32)$ & & & & \\
\hline \multirow{3}{*}{ NDAC-PSO } & $0.8374(6)$ & $0.4739(10)$ & & & & \\
\hline & $0.7970(12)$ & $0.5736(30)$ & 23.5550 & 17.2421 & 0.9813 & 89.9571 \\
\hline & $0.6296(32)$ & $0.3713(31)$ & & & & \\
\hline \multirow{3}{*}{ SCAC-PSO } & $0.7748(10)$ & $0.4407(11)$ & & & & \\
\hline & $1.0305(24)$ & 1.1710 (19) & 25.0973 & 19.6188 & 0.9798 & 89.3695 \\
\hline & $0.9038(32)$ & $1.1789(28)$ & & & & \\
\hline \multirow{3}{*}{ TVA-PSO } & $0.7712(13)$ & $0.7783(4)$ & & & & \\
\hline & $0.7808(24)$ & $0.6314(29)$ & 22.8821 & 17.8931 & 0.9760 & 90.2161 \\
\hline & $0.7731(30)$ & $0.5888(30)$ & & & & \\
\hline
\end{tabular}

(b) IEEE 69-bus

\begin{tabular}{|c|c|c|c|c|c|c|}
\hline & $\begin{array}{c}\text { DG } \\
P(\mathrm{MW}) ; \text { Bus }\end{array}$ & $\begin{array}{c}\text { DSTATCOM } \\
\text { Q(MVar); Bus }\end{array}$ & $P_{\text {Loss' }}, \mathrm{kW}$ & $Q_{\text {Loss }}, \mathrm{kVar}$ & $V_{\text {min }}$, p.u. & APLL, \% \\
\hline \multirow{3}{*}{ Basic PSO } & $0.4175(17)$ & $0.0100(41)$ & & & & \\
\hline & $1.8976(62)$ & $1.5836(61)$ & 14.7216 & 10.9116 & 0.9929 & 93.8572 \\
\hline & $0.0638(67)$ & $0.2137(69)$ & & & & \\
\hline \multirow{3}{*}{ AAC-PSO } & $0.9258(50)$ & $0.7334(40)$ & & & & \\
\hline & $1.6670(63)$ & $1.0379(52)$ & 19.0555 & 10.2770 & 0.9838 & 92.1905 \\
\hline & $0.7815(66)$ & $1.1509(63)$ & & & & \\
\hline \multirow{3}{*}{ APG-PSO } & $0.4614(20)$ & $0.0100(6)$ & & & & \\
\hline & $0.0632(53)$ & $0.0100(54)$ & 12.8728 & 10.3139 & 0.9910 & 94.5873 \\
\hline & $1.6033(61)$ & $1.3875(61)$ & & & & \\
\hline \multirow{3}{*}{ NDAC-PSO } & $0.0100(42)$ & 0.0594 (13) & & & & \\
\hline & $1.9423(62)$ & $0.9283(59)$ & 21.1266 & 13.3832 & 0.9838 & 91.4144 \\
\hline & $0.7921(66)$ & $0.4917(65)$ & & & & \\
\hline \multirow{3}{*}{ SCAC-PSO } & $0.0100(13)$ & $0.7290(29)$ & & & & \\
\hline & $0.2787(25)$ & $0.0100(51)$ & 17.6186 & 12.9267 & 0.9857 & 92.7364 \\
\hline & $1.8718(62)$ & $1.1561(62)$ & & & & \\
\hline \multirow{3}{*}{ TVA-PSO } & $0.9159(12)$ & $0.7785(11)$ & & & & \\
\hline & $0.1344(22)$ & $0.0942(24)$ & 10.6691 & 9.1144 & 0.9886 & 95.4715 \\
\hline & $1.3616(61)$ & $1.2234(61)$ & & & & \\
\hline
\end{tabular}

12,22 and 61 as the optimal locations to install the DG units. Similarly, the buses 11, 24 and 61 are the best locations to install the DSTATCOM units. This integration led to minimizing the active and reactive power loss to $10.6691 \mathrm{~kW}$ and
9.1144 kVar, respectively, which contribute to maximizing the APLL to $95.4715 \%$. This note is valid for the rest of algorithms but with less efficiency compared to the TVA-PSO algorithm. APLL is maximized to 93.8572, 92.1905, 94.5873, 
91.4144 and $92.7364 \%$ in the case of using the basic PSO, AAC-PSO, APG-PSO, NDAC-PSO and SCAC-PSO algorithms, respectively. Furthermore, the voltage profile is improved from 0.9092 to 0.9929 p.u. as in the case of using the basic PSO algorithm.

\section{Study of the efficient energy on EDS}

For the two test systems studied in this paper, the best algorithm is found to be the TVA-PSO if we chose to study the efficient energy of different case studies. Figure 5 represents the effect of the installation of DG, DSTATCOM, and simultaneous operation of DG and DSTATCOM on the voltage profile of each of the two systems.

From Fig. 5, for both test systems, it is clear that the voltages profile is improved for the three case studies (integration of DG only, DSTATCOM only, and simultaneous operation of DG and DSTATCOM) compared to the base case, where the simultaneous installation of DG and DSTATCOM provides more enhancement in the voltages profile.

The minimum voltage is improved from 0.9038 to 0.9760 p.u. for the first test system, and from 0.9092 to 0.9886 p.u. for the second test system in the simultaneous presence of DG and DSTATCOM.

Figure 6 shows the effect of the installation of DG, DSTATCOM, and the simultaneous operation of DG and DSTATCOM on the active power loss of each line branch for each of the two test systems.

Figure 6 shows that the results of the two case studies show that more reduction in active power loss is achieved in the case of simultaneous

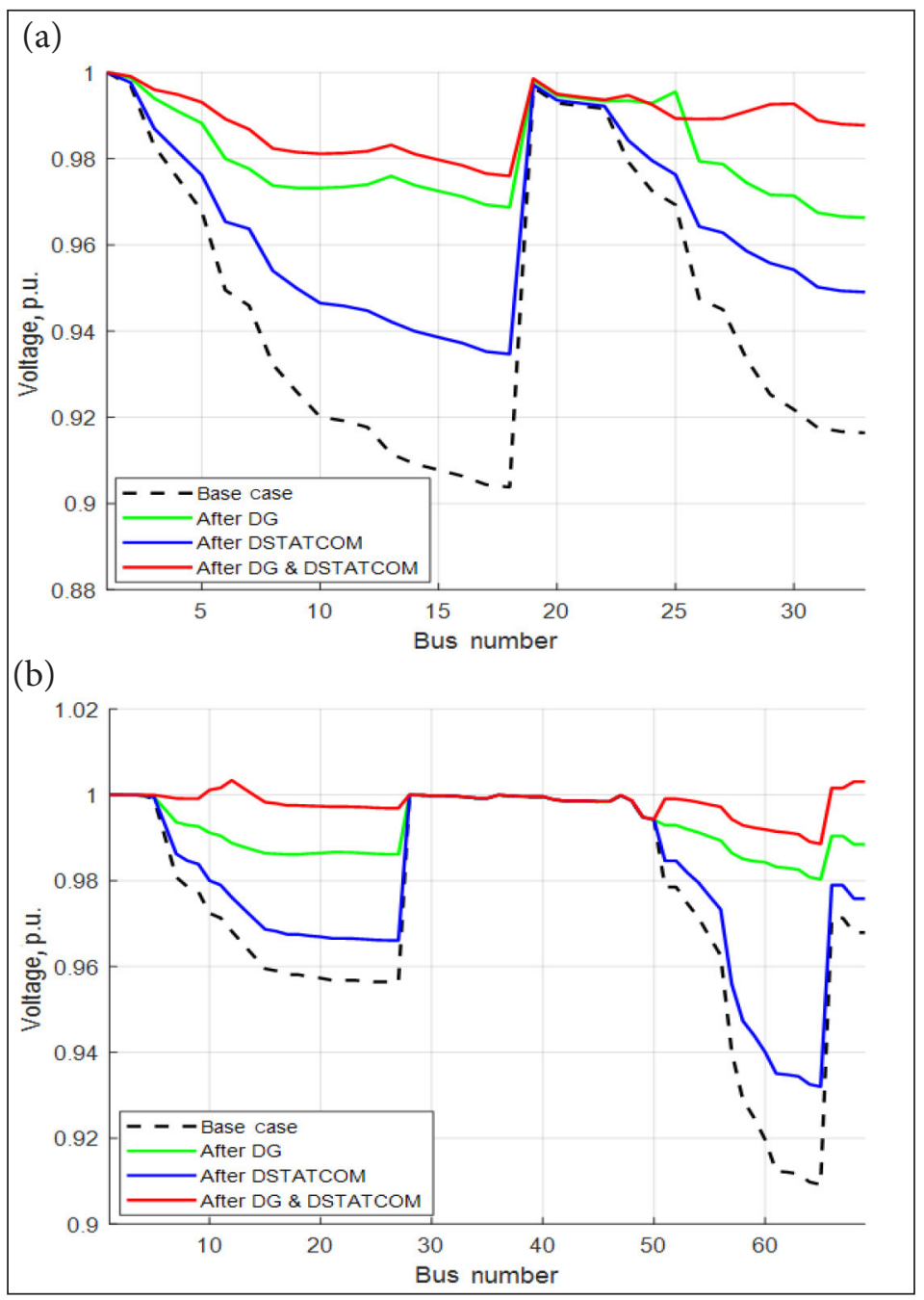

Fig. 5. Bus voltages profile of EDS: (a) IEEE 33-bus, (b) IEEE 69-bus 


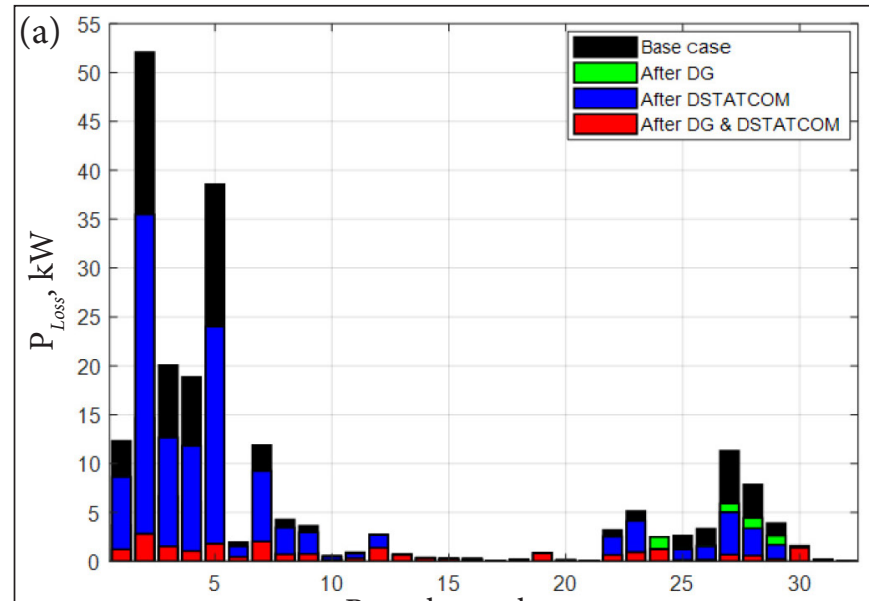

(b)

Branch number

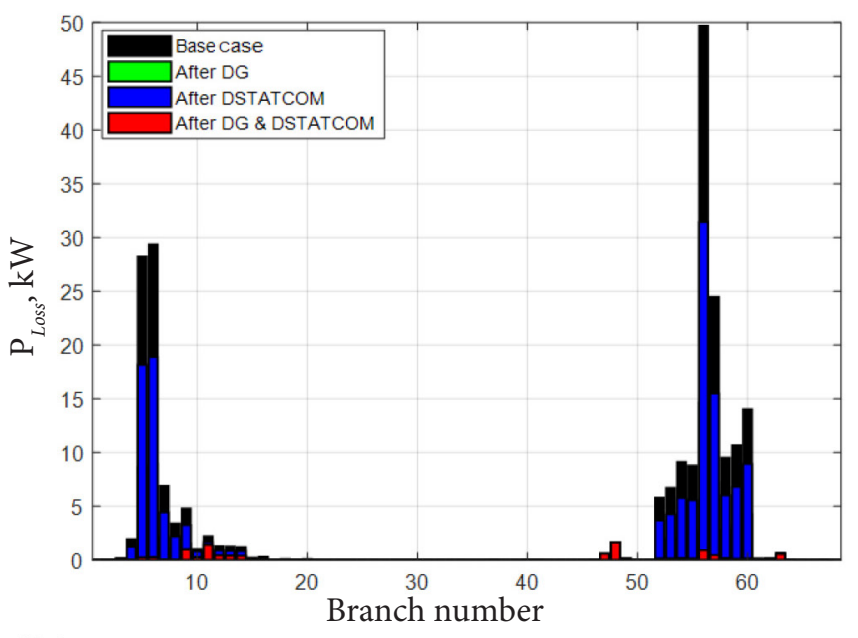

Fig. 6. Active power loss in branches of EDS: (a) IEEE 33-bus, (b) IEEE 69-bus

installation of DG and DSTATCOM for all branches, compared to the other cases (using DG only or DSTATCOM only).

Following the individual integration of DG and DSTATCOM, and the simultaneous installation of DG and DSTATCOM, a noticeable reduction of active power loss is noted in all branches compared to the base case. However, the simultaneous integration of DG and DSTATCOM offers the maximum reduction, which is attributed to injecting active power by DG and reactive power by DSTATCOM at the same time. Concerning the maximum active power loss of branches, it is reduced from 52.0667 to $2.8130 \mathrm{~kW}$ in the first test system, and from 49.6844 to $0.9287 \mathrm{~kW}$ in the second test system.

Figure 7 represents the total power losses (active and reactive) and the minimum bus voltages in the two systems for different case studies.
Figure 7 shows that the comparison among all case studies indicates that the integration of DG and DSTATCOM simultaneously provides more reduction of active and reactive power losses, and achieves the highest minimum voltage profile compared to other case studies of using an individual DG or a DSTATCOM unit.

For the first test system, comparing various case studies indicates that the simultaneous integration of DG and DSTATCOM leads to reducing power loss with a reduction percentage of almost $89.1547 \%$. This is followed by the case of using DG only, where the reduction percentage of power loss becomes close to $64.7905 \%$. Using DSTATCOM only comes last as it encounters the least reduction percentage of power loss, which is $34.1581 \%$. Furthermore, the best (maximum) reduction of reactive power loss and the best voltage values in EDS occur in 


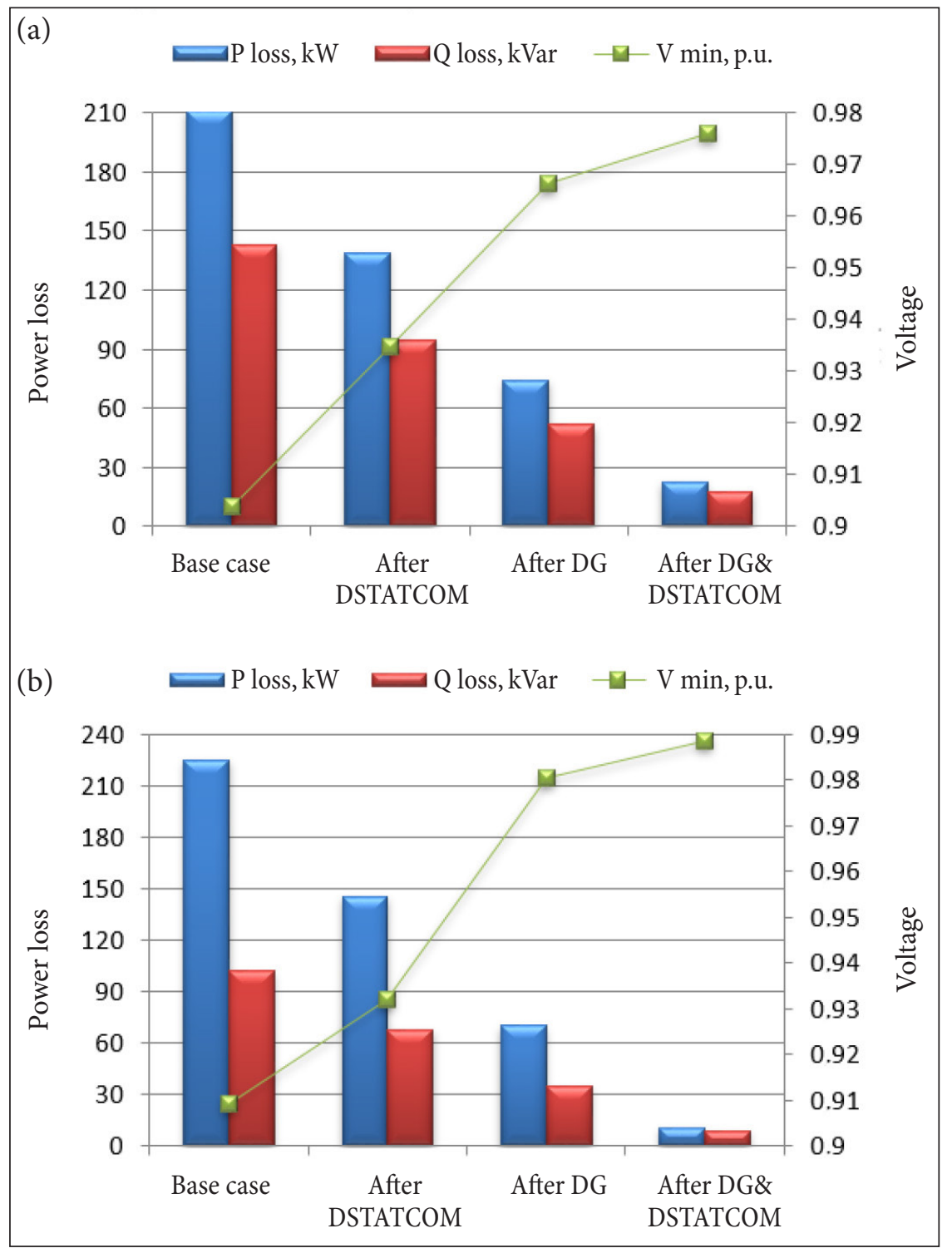

Fig. 7. Active and reactive power losses and minimum voltage of EDS: (a) IEEE 33-bus, (b) IEEE 69-bus

the case of the simultaneous installation of DG and DSTATCOM.

For the second test system, the trend of results obtained is similar to that obtained for the first test system. However, more efficiency is shown in terms of reducing the power loss with a higher reduction percentage, that reaches 95.2570 , 68.6907 and $35.3660 \%$ for the three cases of using DG and DSTATCOM simultaneously, DG only and DSTATCOM only, respectively.

For both test systems, the impact of loadability (variation of load demand) on the total active power losses is investigated in the basic case and in the three cases of integrating the DG and DSTATCOM units. Results are shown in Fig. 8, where load demand has varied from 80 to $120 \%$ with a step of 5\% for all load buses for each of the two test systems.

Figure 8 reveals that the active power losses almost vary in a linear characteristic with the linear variation of loads, in the basic case and after integration of DG or/and DSTATCOM. In addition, the power losses after the simultaneous installation of DG and DSTATCOM are noted to be always smaller than the power losses when using DG only or DSTATCOM only. It is noted that for whatever load increase, the simultaneous integration of DG and DSTATCOM in the system has the ability to achieve a significant reduction in active power loss. 


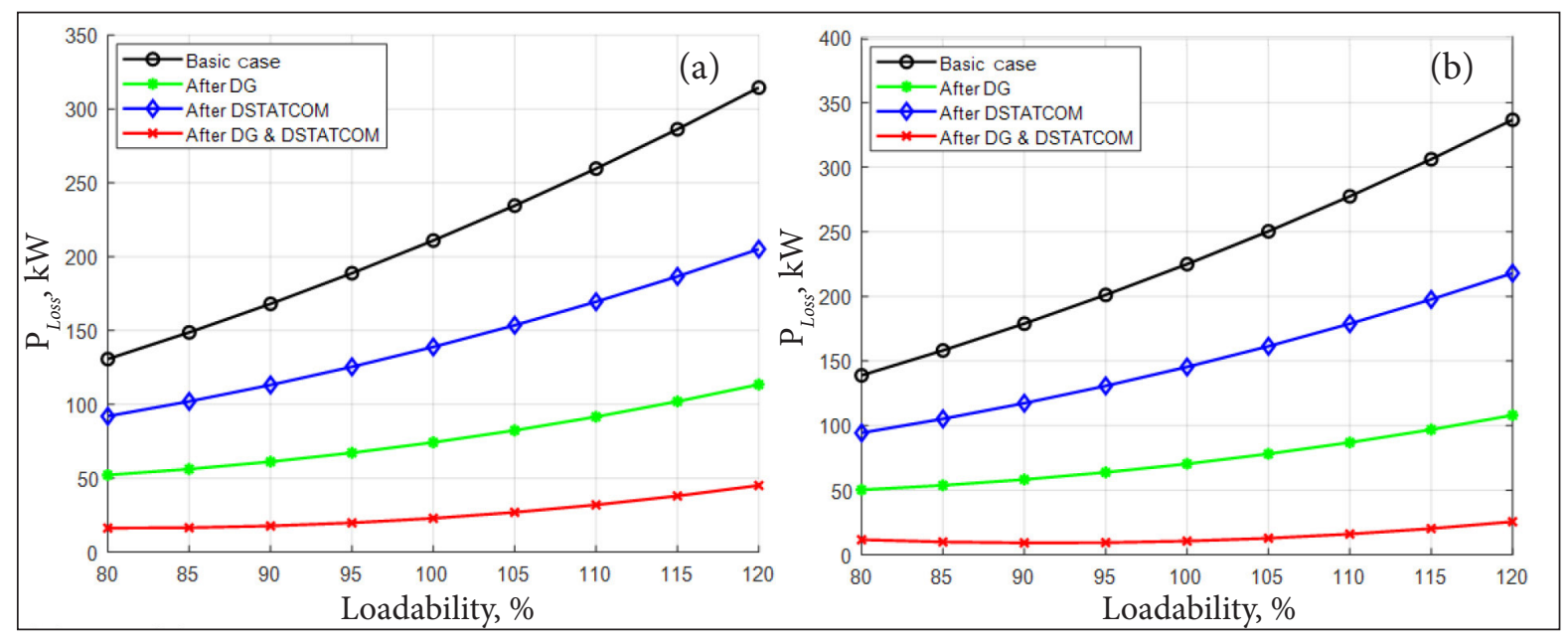

Fig. 8. Active power losses for different loadability values: (a) IEEE 33-bus, (b) IEEE 69-bus

\section{CONCLUSIONS}

In this paper, various PSO algorithms were used to solve the problem of optimal simultaneous integration of the PV-based DG and DSTATCOM units in the standard IEEE 33- and 69-bus EDSs. The optimization is based on a single objective function that aims at maximizing APLL for the best optimal EMS.

The simulation results proved the efficiency and robustness of the TVA-PSO algorithm, compared with other PSO algorithms, in terms of achieving minimum power losses and maxi- mum APLL values with fast convergence characteristics. In addition, the statistical analysis confirms the efficiency of the TVA-PSO algorithm in achieving the best value of APLL when compared with other algorithms. Furthermore, when both DG and DSTATCOM are simultaneously placed, the overall system performance is also improved. This observation is still valid for the two standard IEEE test systems.

From the above discussion, it can be deduced that the TVA-PSO algorithm could be simply applied to practical, large-scale, complex EDSs in electrical power distribution companies.

\section{NOMENCLATURE}

$\begin{array}{ll}P_{\text {Loss' }} Q_{\text {Loss }} & \text { Total active and reactive power losses } \\ P_{i j^{\prime}} Q_{i j} & \text { Active and reactive power in branch ij } \\ P_{i^{\prime}} Q_{i} & \text { Active and reactive power at bus } i \\ P_{j^{\prime}} Q_{j} & \text { Active and reactive power at bus } j \\ N_{\text {bus }} & \text { Number of buses } \\ R_{i j^{\prime}} X_{i j} & \text { Resistance and reactance of line } \\ V_{i^{\prime}} \delta_{i} & \text { Voltage magnitude and angle } \\ P_{G^{\prime}} Q_{G} & \text { Active and reactive power of generator } \\ P_{D^{\prime}} Q_{D} & \text { Active and reactive power of load demand } \\ P_{D G} & \text { Active power injection from PV-DG unit } \\ V_{\min }, V_{\max } & \text { Specified voltages limits } \\ \Delta V_{\max } & \text { Maximum voltage drops } \\ S_{i j} & \text { Apparent power in branch ij }\end{array}$




\begin{tabular}{|c|c|}
\hline$S_{\max }$ & Maximum apparent power \\
\hline$P_{D G}^{\min }, P_{D G}^{\max }$ & Active power output limits of DG \\
\hline$Q_{\text {DSTATCOM }}^{\min }, Q_{\text {DSTATCOM }}^{\max }$ & Reactive power output limits of DSTATCOM \\
\hline$D G_{\text {Position }}$ & Position of DG units \\
\hline DSTATCOM $_{\text {Position }}$ & Position of DSTATCOM units \\
\hline$N_{D G^{\prime}} N_{\text {DSTATCOM }}$ & Number of DG and DSTATCOM units \\
\hline$N_{\text {DG.max' }} N_{\text {DSTATCOM.max }}$ & Maximum number of DG and DSTATCOM units \\
\hline$n_{D G, i^{\prime}} n_{\text {DSTATCOM }, i}$ & Location of DG and DSTATCOM units at bus $i$ \\
\hline$P$ & Population of individuals \\
\hline$X_{i}$ & Position of particle \\
\hline$V_{i}$ & Velocity of particle \\
\hline$P_{\text {best }}$ & Best locations found by particle \\
\hline$G_{\text {best }}$ & Best locations found by all particles \\
\hline$c_{1}$ & The cognitive acceleration factor \\
\hline$c_{2}$ & The social acceleration factor \\
\hline$\omega$ & The inertia weight \\
\hline$r_{1}, r_{2}$ & Random values belong to $[0,1]$ \\
\hline$C_{\min } C_{\max }$ & Limits values of $c_{1}$ and $c_{2}$ \\
\hline$k$ & Number of iterations \\
\hline$k_{\max }$ & Maximum number of iterations \\
\hline
\end{tabular}

Received 21 December 2019 Accepted 20 March 2020

\section{References}

1. Pesaran H. A. M., Huy P. D., Ramachandaramurthy V. K. A review of the optimal allocation of distributed generation: objectives, constraints, methods, and algorithms. Renewable and Sustainable Energy Reviews. 2017. Vol. 75. P. 293-312.

2. Fahad S. A., El-Hawary M. E. Optimal distributed generation allocation and sizing in distribution systems via artificial bee colony algorithm. IEEE Transactions on Power Delivery. 2011. Vol. 26. No. 4. P. 2090-2101.

3. Bouchakour S., Hadj Arab A., Abdeladim K., Ould Amrouche S., Semaoui S., Taghezouit B., Boulahchiche S., Razagui A. Investigation of the voltage quality at PCC of grid connected
PV system. Energy Procedia. 2017. Vol. 141. P. 66-70.

4. Sannigrahi S., Ghatak S. R., Acharjee P. Fuzzy logic-based rooted tree optimization algorithm for strategic incorporation of DG and DSTATCOM. International Transactions on Electrical Energy Systems. 2019. Vol. 29. No. 8. e12031. P. $1-30$.

5. Hien N. C., Mithulananthan N., Bansal R. C. Location and sizing of distributed generation units for loadability enhancement in primary feeder. IEEE Systems Journal. 2013. Vol. 7. No. 4. P. 797-806.

6. Taher S. A., Afsari S. A. Optimal location and sizing of DSTATCOM in distribution systems by immune algorithm. International Journal of Electrical Power \& Energy Systems. 2014. Vol. 60. P. 34-44.

7. Yuvaraj T., Ravi K., Devabalaji K. R. DSTAT$\mathrm{COM}$ allocation in distribution networks 
considering load variations using bat algorithm. Ain Shams Engineering Journal. 2017. Vol. 8. No. 3. P. 391-403.

8. Yuvaraj T., Ravi K. Multi-objective simultaneous DG and DSTATCOM allocation in radial distribution networks using cuckoo searching algorithm. Alexandria Engineering Journal. 2018. Vol. 57. No. 4. P. 2729-2742.

9. Ghatak S. R., Sannigrahi S., Acharjee P. Comparative performance analysis of DG and DSTATCOM using improved PSO based on success rate for deregulated environment. IEEE Systems Journal. 2018. Vol. 12. No. 3. P. 27912802.

10. Bhat M. V., Manjappa N. Flower pollination algorithm based sizing and placement of DG and D-STATCOM simultaneously in radial distribution systems. Proceedings of 20th National Power Systems Conference (NPSC), Tiruchirappalli, India, 14-16 December 2018. P. 1-5.

11. Ahmadnia S., Tafehi E. Comparison of optimum wind-solar DG, STATCOM and capacitor placement and sizing based on voltage stability margin enhancement in microgrid with three different evolutionary algorithms. Iranian Journal of Science and Technology, Transactions of Electrical Engineering. 2017. Vol. 41. No. 3. P. 241-253.

12. El-Ela A. A., El-Sehiemy R. A., Abbas A. S. Optimal placement and sizing of distributed generation and capacitor banks in distribution systems using water cycle algorithm. IEEE Systems Journal. 2018. Vol. 12. No. 4. P. 3629-3636.

13. Sannigrahi S., Ghatak S. R., Acharjee P. Fuzzy logic-based rooted tree optimization algorithm for strategic incorporation of DG and DSTATCOM. International Transactions on Electrical Energy Systems. 2019. Vol. 29. No. 8. P. 1-30.

14. Sannigrahi S., Ghatak S. R., Acharjee P. Strategically incorporation of RES and DSTATCOM for techno-economic environmental benefits using search space reduction-based ICSA. IET Generation, Transmission \& Distribution. 2019. Vol. 13. No. 8. P. 1369-1381.

15. Hassan H. A., Zellagui M. MVO algorithm for optimal simultaneous integration of DG and DSTATCOM in standard radial distribution systems based on technical-economic indices. Proceedings of 21st International Middle East
Power Systems Conference (MEPCON), Tanta, Egypt, 17-19 December 2019. P. 277-282.

16. Pottukkannan B., Thangaraj Y., Kaliyaperumal D., Abdul Rasheed M. I., Perumal M. P. Integration of solar and wind based DGs with DSTATCOM in distribution systems using modified bat algorithm. Gazi University Journal of Science. 2019. Vol. 32. No. 3. P. 895-912.

17. Salkuti S. R. Optimal location and sizing of DG and D-STATCOM in distribution networks. Indonesian Journal of Electrical Engineering and Computer Science. 2019. Vol. 16. No. 3. P. 11071114.

18. Sannigrahi S., Ghatak S. R., Acharjee P. Multi-scenario based bi-level coordinated planning of active distribution system under uncertain environment. IEEE Transactions on Industry Applications. 2020. Vol. 56. No. 1. P. 850-863.

19. Rezaeian-Marjani S., Galvani S., Galvanat V., Farhadi-Kangarlu M. Optimal allocation of D-STATCOM in distribution networks including correlated renewable energy sources. International Journal of Electrical Power \& Energy Systems. 2020. Vol. 122. P. 1-14.

20. Yuvaraj T., Devabalaji K. R., Thanikanti S. B. Simultaneous allocation of DG and DSTATCOM using whale optimization algorithm. Iranian Journal of Science and Technology, Transactions of Electrical Engineering. 2020. Vol. 44. P. 879896.

21. Settoul S., Chenni R., Hassan H. A., Zellagui M., Kraimia M. N. MFO algorithm for optimal location and sizing of multiple photovoltaic distributed generations units for loss reduction in distribution systems. Proceedings of 7th International Renewable and Sustainable Energy Conference (IRSEC), Agadir, Morocco, 27-30 November 2019. P. 1-6.

22. Shukor S. F. A., Musirin I., Hamid Z. A., Zamani M. K. M., Zellagui M., Suyono H. Intelligent based technique for under voltage load shedding in power transmission systems. Indonesian Journal of Electrical Engineering and Computer Science. 2020. Vol. 17. No. 1. P. 110-117.

23. Settoul S., Zellagui M., Abdelaziz A. Y., Chenni R. Optimal integration of renewable distributed generation in practical distribution grids based on moth-flame optimization algorithm. Proceedings of International Conference on Advanced Electrical 
Engineering (ICAEE), Algiers, Algeria, 19-21 November 2019. P. 1-6.

24. Kellogg W. D., Nehrir M. H., Venkataramanan G., Gerez V. Generation unit sizing and cost analysis for stand-alone wind, photovoltaic, and hybrid wind/PV systems. IEEE Transactions on Energy Conversion. 1998. Vol. 13. No. 1. P. 70-75.

25. Eberhart R., Kennedy J. A new optimizer using particle swarm theory. Proceedings of 6 th International Symposium on Micro Machine and Human Science (MHS), Nagoya, Japan, 4-6 October 1995. P. 39-43.

26. Ziyu T., Dingxue Z. A modified particle swarm optimization with an adaptive acceleration coefficients. Proceedings of IEEE Asia-Pacific Conference on Information Processing (APCIP), Shenzhen, China, 18-19 July 2009. P. 330-332.

27. Mirjalili S., Lewis A., Sadiq A. S. Autonomous particles groups for particle swarm optimization. Arabian Journal for Science and Engineering. 2014. Vol. 39. No. 6. P. 4683-4697.

28. Chen K., Zhou F., Wang Y., Yin L. An ameliorated particle swarm optimizer for solving numerical optimization problems. Applied Soft Computing. 2018. Vol. 73. P. 482-496.

29. Chen K., Zhou F., Yin L., Wang S., Wang Y., Wan F. A hybrid particle swarm optimizer with sine cosine acceleration coefficients. Information Sciences. 2018. Vol. 422. P. 218-241.

30. Ratnaweera A., Halgamuge S. K., Watson H. C., Self-organizing hierarchical particle swarm optimizer with time-varying acceleration coefficients. IEEE Transactions on Evolutionary Computation. 2004. Vol. 8. No. 3. P. 240-255.
Adel Lasmari, Mohamed Zellagui, Rachid Chenni, Smail Semaoui,

Claude Ziad El-Bayeh, Heba Ahmed Hassan

\section{SKIRSTOMŲJU巳 TINKLŲ OPTIMALIAM}

ENERGIJOS VALDYMUI SISTEMA SU SAULĖS MODULIAIS IR DSTATCOM TECHNOLOGIJA

\section{Santrauka}

Skirstomojo tinklo energijos valdymo sistema (EMS), i kurią integruota paskirstyta generacija ir statinis skirstomųjų tinklų kompensatorius (DSTATCOM), pasižymi daugybe privalumų ir labai skiriasi nuo kitų, šiuo metu skirstomuosiuose tinkluose esančių, sistemų. Straipsnyje pristatoma optimali saulès elektrinès ir DSTATCOM integracija i skirstomąji tinklą. Optimaliai galiai ir vietai nustatyti naudojama vieno kriterijaus funkcija, ieškanti aktyviosios galios nuostolių maksimumo, esant skirtingiems, tyrime užsiduotiems, scenarijams, ir naudojant ịvairius daleliu spiečių optimizacijos (PSO) algoritmus. Naudojamas paprastasis PSO, adaptyviai greitejjančių koeficientų PSO (AA-PSO), autonominių dalelių grupių PSO (APG-PSO), netiesinių greitėjančių koeficientų PSO (NDAC-PSO), pagal sinusoidès (kosinusoidès) dèsnị greitëjančių koeficientų PSO (SCAC-PSO) ir bègant laikui kintančio greitėjimo PSO (TVA-PSO). Algoritmų efektyvumas (adekvatumas) testuojamas IEEE standarto 33 ir 69 šynų sistemoje. Modeliavimas atskleide, kad efektyviausias ir geriausiai tinkantis yra TVA-PSO algoritmas. Saulès elektrinei ir DSTATCOM parenkama optimali vieta, kas sumažina aktyviosios galios nuostolius ir pakelia įtampos lygị.

Raktažodžiai: energijos valdymo sistema (EMS), energijos skirstymo sistema (EDS), atsinaujinantys energijos šaltiniai (RES), paskirstyta generacija (DG), skirstomųjų tinklų statinis kompensatorius (DSTATCOM), aktyviosios galios nuostoliu lygis (APLL), dalelių spiečiaus optimizacijos algoritmas (PSO) 